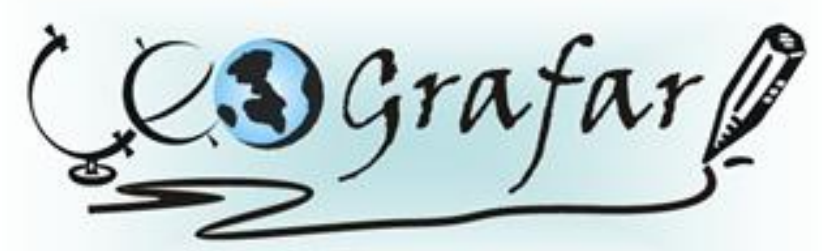

Revista Eletrônica do Programa de Pós-Graduação em Geografla - UFPR

\title{
ESTUDO DA DEGRADAČ̃̃ E DO IMPACTO SÓCIO-AMBIENTAL NA BACIA DO CÓRREGO OSÓRIO, MARINGÁ - PARANÁ
}

\author{
SANDRA APARECIDA MACHADO SESCO ${ }^{1}$ \\ CARLOS HENRIQUE DA GRAÇA ${ }^{2}$ \\ HÉLIO SILVEIRA ${ }^{3}$
}

\begin{abstract}
RESUMO: É de fundamental importância os estudos que visam correlacionar os atributos do ambiente em seus aspectos físicos e humanos. Deste modo, atribuiu-se ao estudo a palavra sócioambiental, onde o sócio refere-se à sociedade e, ambiental ao ambiente natural, que atualmente encontra-se em sua maior parte modificado pela ação antrópica. Contudo, o presente trabalho, tem por objetivo mapear, correlacionar, avaliar e contribuir para o estudo e avaliação dos impactos sócioambientais na bacia do córrego Osório, visando determinar as classes de fragilidade e/ou vulnerabilidade sócio-ambiental. A área de estudo localiza-se na cidade de Maringá entre os paralelos $23^{\circ} 23^{\prime} 01^{\prime \prime}$ a $23^{\circ} 25^{\prime} 13^{\prime \prime}$ de latitude Sul e os meridianos $51^{\circ} 53^{\prime} 23^{\prime \prime}$ a $51^{\circ} 54^{\prime} 09^{\prime \prime}$ de longitude Oeste, no Estado do Paraná. A metodologia proposta por Simielli (1999) e a adaptação da metodologia proposta por Crepani et al. (1996) e Graça e Silveira $(2008$; 2009) forneceram subsídios para o estudo, correlação das informações e levantamento de dados. Assim, foram correlacionados os atributos do meio físico, como: declividade, vegetação e, sócio-econômico, como: presença de estabelecimentos comerciais impactantes, impermeabilização do solo, galerias pluviais e canalização do córrego, processos erosivos e áreas de empréstimo de terra e despejo de resíduos sólidos. Desta forma, o material cartográfico gerado possibilitou a correlação das informações, aonde se chegou as quatro classes de fragilidade e/ou vulnerabilidade sócio-ambiental: baixa, média, forte e muito forte para a bacia estudada, porém com predomínio da classe forte. Contudo, conclui-se que na bacia do córrego Osório os problemas existentes quanto à degradação e impactos foram intensificados devido à ação antrópica, sendo necessária, uma maior fiscalização e conscientização da população local, para que possa minimizar a degradação e os impactos causados na bacia.
\end{abstract}

Palavras chave: Degradação e impacto ambiental; fragilidade e vulnerabilidade sócio-ambiental; bacia do córrego Osório.

\section{STUDY OF DEGRADATION AND ENVIRONMENTAL AND SOCIAL IMPACT IN STREAM BASIN OSÓRIO, MARINGÁ - PARANÁ}

\begin{abstract}
The studies that correlate the attributes of the environment in physical and human terms are of fundamental importance. Thus, the word socio-environmental is attributed to the study, where the member refers to the society and environmental to the natural environment, which currently is largely modified by human action. However, this work aims to map, correlate, evaluate and contribute to the study and evaluation of environmental and social impacts in the basin of the stream Osório, in order to determine the fragility classes and / or socio-environmental vulnerability. The study area is located in the city of Maringá between parallels $2323^{\prime} 01$ "to $23 \cong 25^{\prime} 13^{\prime \prime}$ south latitude and meridians $51^{\circ} 53^{\prime} 23$ "51 - 54'09" West, in the State of Paraná. The methodology proposed by Simielli (1999) and

\footnotetext{
1 Licenciada e Bacharel em Geografia - UEM (sandrasesco@hotmail.com).

${ }^{2}$ Bolsista do Projeto Universidade Sem Fronteiras - SETI/PR (2010), Licenciado e Bacharel em Geografia - UEM (riquechg@hotmail.com).

${ }^{3}$ Professor Doutor do Departamento de Geografia - UEM (hesilveira70@hotmail.com).
} 
adaptation of the methodology proposed by Crepani et al. (1996) and Graça and Silveira (2008; 2009) provided support for the study, correlation of information and data collection. Therefore, we correlated the attributes of the physical environment, such as slope, vegetation and socio-economic, such as presence of commercial impacts, soil sealing, storm sewers and wastewater stream, erosion and areas of land loan and solid waste disposal. As a result, the cartographic material generated enabled the correlation of information, reaching in the four classes socio-environmental fragility and/or vulnerability - low, medium, strong and very strong for the basin studied, but with a predominance of the strong class. However, it is concluded that the basin of the stream Osório the existing problems regarded to degradation and impacts were intensified due to human action, requiring greater control and awareness of local people, so that the degradation and the impacts in the basin may be minimized.

Keywords: Degradation and environmental impact, fragility and vulnerability socio-environmental; basin stream Osório.

\section{INTRODUÇÃO}

Todo desenvolvimento tem o seu preço e na atualidade, discute-se muito os problemas ambientais proporcionados pela urbanização.

Nesse contexto, os problemas ambientais intensificaram-se a partir das transformações do meio ambiente, decorrentes, dentre outros fatores, do acelerado processo de ocupação do espaço e apropriação dos recursos naturais pelo homem. Assim, os estudos sócio-ambientais fazem-se necessários para o planejamento e um melhor manejo destas áreas.

Esta preocupação em planejar as cidades foi uma das características da Companhia Melhoramentos Norte do Paraná (CMNP) responsável pela fundação da maioria das cidades do Norte - Noroeste do Estado. No entanto, com a cidade de Maringá não poderia ser diferente, seus traçados iniciais foram estabelecidos a partir de sua topografia, ocupação e desenvolvimento urbano, que ocorreram de montante para jusante, proporcionando na atualidade a degradação das nascentes e cursos d'água localizados na área urbana. Dessa forma, Zamuner (2001) acrescenta que apesar do planejamento urbano-viário original, a cidade de Maringá, apresenta inúmeros problemas ambientais por conta de seu acelerado e desordenado crescimento urbano.

Ainda de acordo com Zamuner (2001), pelo aumento da população, e com o intuito de atender suas necessidades básicas, ocorrem as modificações no meio físico, que é representada em parte pela impermeabilização da superfície e pela geração de um sistema de drenagem urbana artificial. Quando esse escoamento 
superficial ocorre de forma direta nos corpos hídricos, originam impacto ambiental, em área urbana e na sua periferia.

Segundo Tucci (1995) é por meio do desenvolvimento urbano, que ocorre a impermeabilização do solo, isso, através de telhados, ruas, calçadas e pátios, entre outros. Dessa forma, a parcela da água que infiltrava passa a escoar pelos condutos, aumentando o escoamento superficial. Assim, o volume que escoava lentamente pela superfície do solo e eram retidas pelas plantas, com a urbanização, passa a escoar no canal, exigindo maior capacidade de escoamento.

Assim, os principais problemas ambientais existentes na cidade de Maringá, foram caracterizados por Garcia (2006), dos quais merece destaque 0 desmatamento, o desrespeito com a legislação das Áreas de Preservação Permanente - fundos de vale, a erosão, o lixo urbano, a poluição visual urbana, a poluição do ar, a qualidade da água e os problemas gerados pela drenagem urbana.

Como conseqüência da expansão urbana ocorrente na cidade de Maringá devido ao recebimento de um grande contingente de pessoas vindas de outras cidades ou Estados, houve a necessidade de agregar as áreas periféricas de seu núcleo central, absorvendo assim áreas onde anteriormente era rural com predomínio de grandes fazendas produtoras de café, deram lugar a loteamentos e novos bairros, como exemplo disso tem-se a bacia do córrego Osório que teve seu processo de urbanização iniciado na década de 1960 e, atualmente, apresenta-se praticamente toda impermeabilizada o que ocasionou problemas com a degradação e impactos ambientais principalmente nas proximidades de seu curso.

Desta forma, o presente trabalho, tem por objetivo mapear, correlacionar, avaliar e contribuir para o estudo dos impactos sócio-ambientais na bacia do córrego Osório, visando determinar as classes de fragilidade e/ou vulnerabilidade sócioambiental. 


\section{MATERIAL E MÉTODO}

\section{Localização da área de estudo}

A bacia do córrego Osório situa-se no setor Nordeste da cidade de Maringá, entre os paralelos $23^{\circ} 23^{\prime} 01^{\prime \prime}$ a $23^{\circ} 25^{\prime} 13^{\prime \prime}$ de latitude Sul e os meridianos $51^{\circ} 53^{\prime} 23^{\prime \prime}$ a 51 $54^{\circ}$ '09" de longitude Oeste, porção Norte do Estado do Paraná, que corresponde ao Terceiro Planalto Paranaense (MAACK, 1968). Abrangendo uma superfície aproximada de $3,8 \mathrm{~km}^{2}$ e 9,2 km de perímetro (Figura 1).

\section{FIGURA 1: LOCALIZAÇÃO DA ÁREA DE ESTUDO.}

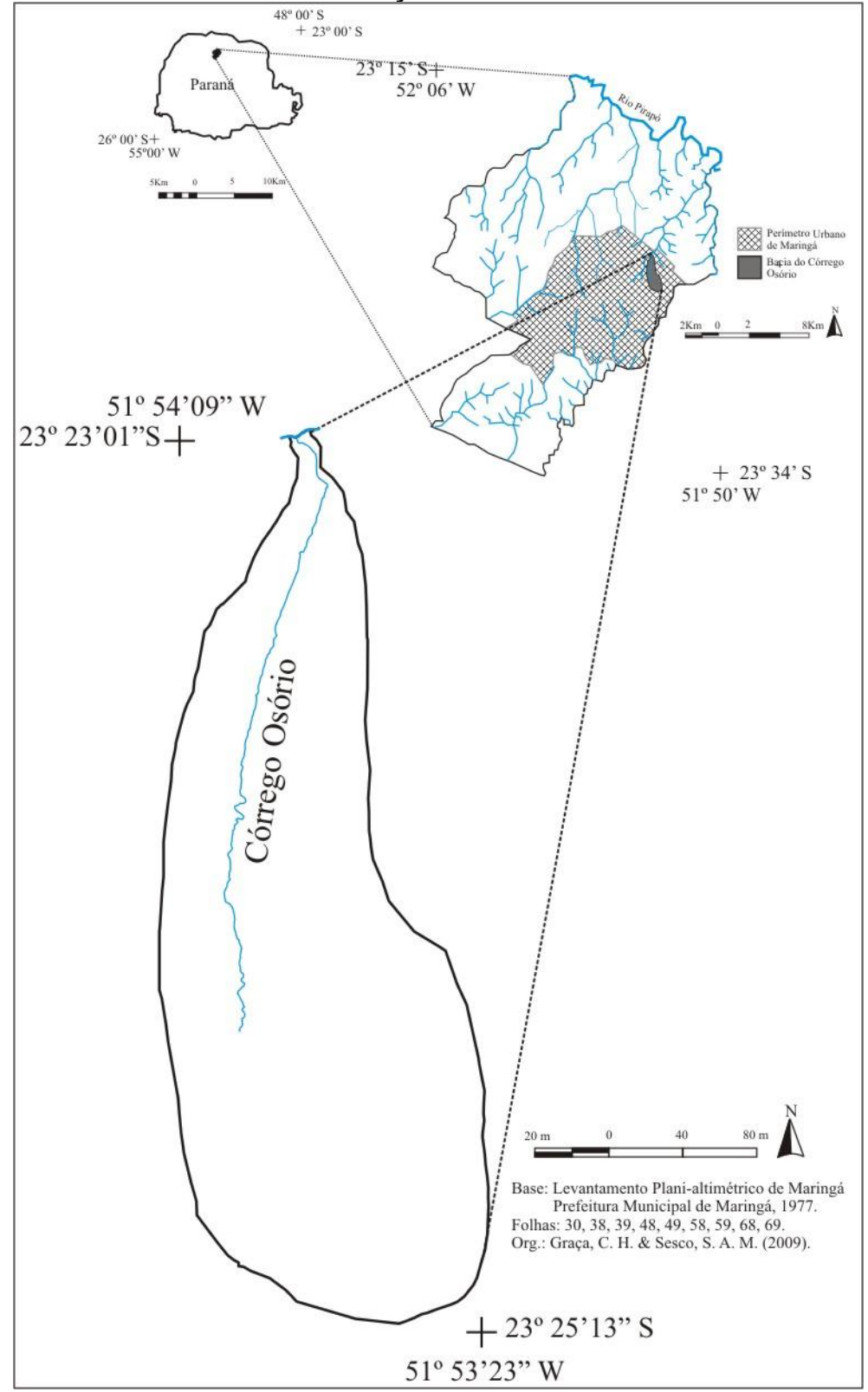




\section{ASPECTOS DO MEIO FÍSICO}

O clima predominante na região, segundo classificação de Köeppen (1948) é subtropical úmido mesotérmico (Cfa), apresentando verões quentes e geadas pouco freqüente. A temperatura média do mês mais quente é superior a $22^{\circ} \mathrm{C}$ e o mês mais frio apresenta temperatura abaixo de 18으 (IAPAR, 1978).

Quanto às chuvas, tem-se uma boa distribuição na precipitação durante o ano, com uma ligeira diminuição na precipitação nos meses de inverno. A precipitação média anual para o município varia entre 1.250 a $1.500 \mathrm{~mm}$, porém, mais concentradas na primavera e verão (IAPAR, 1978; ANJOS, 2000).

A vegetação natural é classificada como remanescentes da Floresta Estacional Semidecidual, conhecida como Mata Atlântica de interior (PARANÁ, 1987), onde encontra-se espécies variadas como: Canela, Peroba, Pau D' Alhos, Palmito Branco, Cedro, Ingá, Figueira, dentre outras.

Geologicamente a bacia do córrego Osório está dentro da Formação Serra Geral, caracterizada por rochas eruptivas, predominantemente 0 basalto (MINEROPAR, 2006).

Os principais solos encontrados no município de Maringá são os LATOSSOLOS VERMELHO e NITOSSOLO VERMELHO, que apresentam textura argilosa a muito argilosa (EMBRAPA, 1999).

O relevo da região de Maringá apresenta declividade pouco acentuada e altitudes compreendidas entre 300 a 600 metros em relação ao nível do mar. Apresentando-se na bacia do córrego Osório com altitudes que variam de 450 a 570 metros.

\section{ASPECTOS HISTÓRICOS E SÓCIO-ECONÔMICOS DA CIDADE DE MARINGÁ}

A cidade de Maringá é uma das dezenas de cidades fundadas pela Companhia Melhoramentos Norte do Paraná (CMNP), sendo planejada para ser um dos centros regionais do Norte do Estado (MENDES; GRZEGORCZYZ, 2003). 
Desde sua fundação (10 de maio de 1947) a cidade de Maringá nunca deixou de ter um contínuo e progressivo desenvolvimento urbano. Embora o desenvolvimento sócio-econômico inicial, foi impulsionado pela produção de café na década de 1950, a partir de meados da década de 1960, já acusava a presença das modificações sócio-econômicas, manifestada, regionalmente pela modernização da agricultura após a crise proporcionada devido a Segunda Guerra Mundial, e o aprofundamento da agroindústria (MORO, 2003).

De acordo com Luz (1997) Maringá tornou-se rapidamente um dos principais núcleos urbanos criados pela CMNP. Dessa forma em 14 de fevereiro de 1951 foi elevada à categoria de Município por meio da Lei n.․790 e em 09 de março de 1954 foi instalada a Comarca de Maringá.

O desenho da estrutura urbana de Maringá decorre de um moderno projeto urbanístico, elaborado pelo arquiteto e urbanista Jorge de Macedo Vieira, que identificava-se com as diretrizes das "Cidades Jardins" e da "Carta de Atenas", objetivando um desenvolvimento harmônico. O projeto previa a estruturação espacial da cidade em zonas funcionais: residencial, comercial, industrial, médicohospitalar e administrativa, que foram previamente definidas, articuladas entre si por amplas avenidas que teriam arborização lateral e central, enquanto as ruas teriam arborização lateral, além de quatro bosques no quadro urbano: Parque do Ingá, Parque dos Pioneiros, Parque das Grevíleas e Horto Florestal (MORO, 2003).

Em meados da década de 1970, já superando o ciclo cafeeiro, a produção agrícola passou a refletir a introdução do complexo agroindustrial. Ocorreu então a maciça modernização e mecanização do campo. As lavouras cafeeiras, grandes empregadoras de mão-de-obra, passaram a ceder lugar às lavouras mecanizadas, sofrendo profundas transformações nas relações de trabalho e no meio rural (RIGON, 2005).

Assim, Maringá assumiu uma posição de pólo regional, com elevada centralidade, apresentando crescimento urbano, ultrapassando áreas do planejamento inicial. Dessa forma, o êxodo rural instalou-se com rigor, o perímetro urbano povoa-se, novos loteamentos foram criados, alguns irregulares, isso para atender a demanda dos retirantes do campo. Dessa forma, na cidade de Maringá, ocorreu à expansão urbana e a administração pública e os agentes privados 
procuraram equipar a cidade para atender o contingente de novos habitantes, sendo necessárias a implantação imediata de rede de água potável e estender a rede de energia (MORO, 2003).

Com o continuo processo de ocupação na cidade de Maringá, as áreas que até então não eram pertencentes aos traçados iniciais da cidade, foram sendo ocupadas. O perímetro urbano de Maringá aumentou em relação à área rural em todas as direções, consequentemente não foi exceção à ocupação da bacia do córrego Osório.

Desta forma, surgiram os bairros existentes na bacia do córrego Osório, a partir da década de 1970, intensificando-se essa ocupação a partir do ano de 2000, onde se apresenta atualmente quase que toda urbanizada.

\section{MÉTODO}

Serviu como base para a elaboração do presente trabalho, a bacia do córrego Osório, localizado na área urbana da cidade de Maringá - PR. Embora apresentando características naturais, esta bacia encontra-se praticamente toda impermeabilizada, apresentando-se como a continuidade do processo de ocupação ocorrido na cidade de Maringá, desde a década de 1950.

O método adotado baseia-se no levantamento de dados e correlação das características físicas e sócio-econômicas da bacia do córrego Osório, visando detectar os locais com maior fragilidade e/ou vulnerabilidade sócio-ambiental.

Para se chegar a tal estudo utilizou-se primeiramente a metodologia apresentada por Simieli (1999), que adota três níveis de pesquisa por meio cartográfico, que ajudará na análise de cada fenômeno ocorrente na área da bacia, sendo:

1. Localização e Análise: cartas de análise, distribuição ou repartição, que analisam o fenômeno isoladamente.

2. Correlação: permite a combinação de duas ou mais cartas de análise. 
3. Síntese: mostra a relação entre várias cartas de análise, apresentando em uma carta síntese.

Por meio da elaboração, análise e correlação das cartas temáticas de declividade, vegetação, impermeabilização, erosão, galerias pluviais, despejo de lixo e atividades comerciais impactantes, pode-se atingir os dois primeiros níveis proposto por Simieli (1999).

Para se obter o terceiro nível proposto por Simieli (1999) e estabelecer as classes de fragilidade e/ou vulnerabilidade sócio-ambiental, adaptou-se a metodologia proposta por Crepani et al. (1996), assim como seqüência e aperfeiçoamento da metodologia abordada por Graça e Silveira (2008; 2009).

Na representação das áreas de fragilidade e/ou vulnerabilidade sócio-ambiental da bacia do Córrego Osório, pode-se chegar a quatro níveis de classificação: Baixa, Média, Forte e Muito Forte.

Contudo, para elaboração da carta síntese ou Classes de fragilidade e/ou vulnerabilidade sócio-ambiental do córrego Osório, foi correlacionada às informações sobre: a declividade, a impermeabilização do solo, o grau de proteção da vegetação, o despejo de resíduos sólidos, o sistema de contenção de águas pluviais e canalização do córrego, a presença de áreas com empréstimo de terra e processos erosivos e as atividades comerciais impactantes.

Para identificar os diferentes tipos de resíduos sólidos existentes na área estudada, utilizou-se da classificação elaborada pela ABNT (Associação Brasileira de Normas Técnicas), através da NBR - 10.004 - Resíduos Sólidos - Classificação, que em 1987, atribui ao lixo à expressão "Resíduos Sólidos".

Dessa forma, os resíduos sólidos são classificados da seguinte forma:

a) Resíduos Classe 1 - perigosos: aqueles que apresentam riscos à saúde pública e ao meio ambiente, exigindo tratamento e disposição especial em função de suas características de inflamabilidade, corrosividade, reatividade, toxidade e patogenicidade;

b) Resíduos Classe 2 - não-inertes: são os resíduos que não apresentam periculosidade, porém não são inertes; podem ter propriedades tais como: combustibilidade, biodegradabilidade ou solubilidade em água. São basicamente os resíduos com as características do lixo doméstico; 
c) Resíduos Classe 3 - inertes: são aqueles que, ao serem submetidos aos testes de solubilidade (NBR10.007 da ABNT), não têm nenhum de seus constituintes solubilizados em concentrações superiores aos padrões de potabilidade da água.

Para cada item analisado atribuiu-se uma pontuação de acordo com o grau de importância (degradação e impacto ambiental), representados na Tabela 1, e para definir as classes de fragilidade e/ou vulnerabilidade sócio-ambiental, foi considerada as somas entre 2 a 7 - baixa fragilidade; 08 a 10 - média fragilidade; 11 a 18 - forte fragilidade; e maior que 18 - muito forte fragilidade.

TABELA 1: ATRIBUTOS DO MEIO FÍSICO E SÓCIO-ECONÔMICO LEVANTADOS NA BACIA DO CÓRREGO OSÓRIO.

\begin{tabular}{|c|c|c|c|}
\hline ATRIBUTOS & Pesos & ATRIBUTOS & Pesos \\
\hline \multicolumn{2}{|l|}{ Declividade\% } & \multicolumn{2}{|l|}{ Floresta Ciliar / Vegetação } \\
\hline Muito Fraca: $0-2$ & 1 & Grau de proteção Alto & 1 \\
\hline Fraca: $2-5$ & 2 & Grau de proteção Médio & 4 \\
\hline Média: 5 - 10 & 3 & Grau de proteção Baixo & 8 \\
\hline Forte: $10-20$ & 4 & & \\
\hline Muito Forte: 20 - 30 & 5 & \multicolumn{2}{|l|}{ Resíduos Sólidos Urbanos } \\
\hline \multirow[t]{2}{*}{ Extremamente Forte: $>30$} & 6 & Resíduos Inertes (Classe 3) & 4 \\
\hline & & Resíduos Não-Inertes (Classe 2) & 6 \\
\hline \multicolumn{2}{|l|}{ Impermeabilização } & Resíduos Perigosos (Classe 1) & 10 \\
\hline Sem impermeabilização & 1 & & \\
\hline Impermeabilizado & 8 & \multicolumn{2}{|l|}{ Atividades Comerciais Impactantes } \\
\hline & & Resíduos de oficinas mecânicas & 2 \\
\hline \multicolumn{2}{|l|}{ Despejo de Galerias Pluviais } & Lava-jatos & 4 \\
\hline Pontos Canalização do córrego & 6 & Posto de Gasolina & 6 \\
\hline Despejo Direto & 8 & & \\
\hline \multicolumn{4}{|l|}{ Empréstimo de terra e Erosão } \\
\hline Empréstimo de terra & 3 & & \\
\hline Sulcos Rasos & 5 & & \\
\hline Sulcos Profundos & 8 & & \\
\hline
\end{tabular}

Elaboração: SESCO, S. (2009). Adaptado: GRAÇA, C.H. (2008).

\section{ELABORAÇÃO DOS PRODUTOS CARTOGRÁFICOS}

Para a elaboração das cartas temáticas foram utilizadas imagens de satélite (julho de 2005) obtidas por meio do Software Google Earth (2009) e à carta base do município de Maringá, folhas: 30, 38, 39, 48, 49, 58, 59, 68, 69 que estão na escala 1: 2000 e eqüidistância entre as curvas de nível de 1 metro, adquiridas em arquivo no formato TIF, elaboradas pela Prefeitura Municipal de Maringá (1977). Estas 
cartas plani-altimétricas foram digitalizadas utilizando o Software Corel Draw X4 (2008) mantendo-se a escala.

Após levantamento, identificação e hierarquização dos dados, utilizou-se o Software Corel Draw X4 (2008) para elaboração das cartas temáticas: declividade, hipsometria; evolução urbana e limite entre os bairros; impermeabilização; vegetação e áreas delimitadas para reflorestamento nas margens do córrego; escoamento superficial e empréstimo de terra; despejo de águas pluviais e canalização do córrego; classes de resíduos urbanos; atividades comerciais impactantes; correlação; e fragilidade e/ou vulnerabilidade sócio-ambiental.

\section{RESULTADOS E DISCUSSÕES}

O córrego Osório apresenta a primeira ordem de ramificação, segundo classificação de Strahler (1964). Apresentando um formato senoidal, é sinuoso, perene o ano todo, possuindo uma extensão de aproximadamente 2.810 metros (Figura 2). 
FIGURA 2: REDE DE DRENAGEM DA BACIA DO CÓRREGO OSÓRIO.

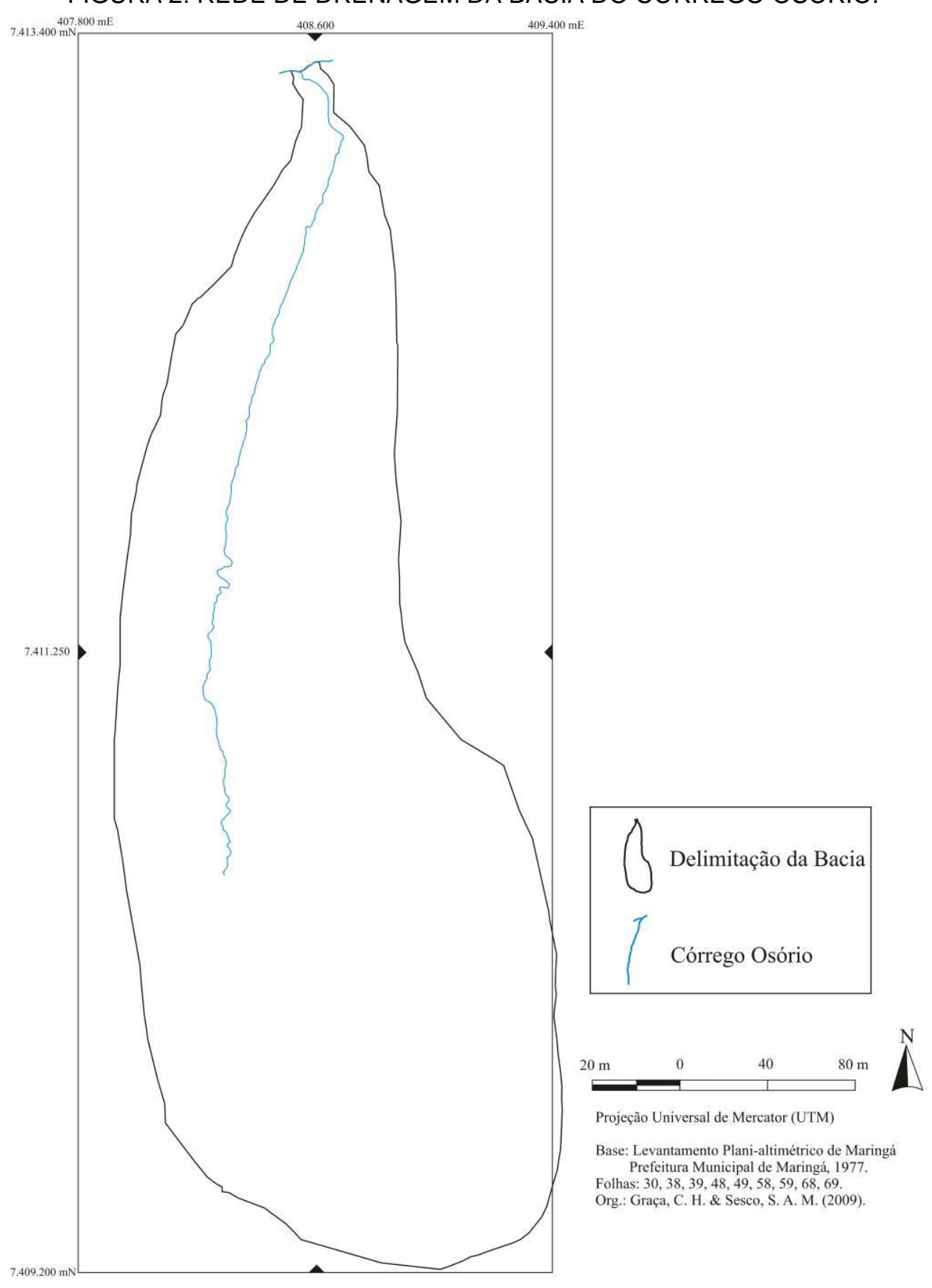

O relevo da área da bacia do córrego Osório vária de plano a forte ondulado, notando-se o predomínio de declividades que variam de 2 a $5 \%$ e 5 a $10 \%$, que estão mais próximas a borda da bacia. Na margem direita e esquerda do córrego encontram-se áreas significativas com de declividades que variam de 10 a $20 \%$. E em alguns pontos próximos ao leito do córrego, embora sendo menos expressivas, ocorrem às declividades de 20 a 30\% e > 30\% (Figura 3). 
FIGURA 3: DECLIVIDADE DA BACIA DO CÓRREGO OSÓRIO.

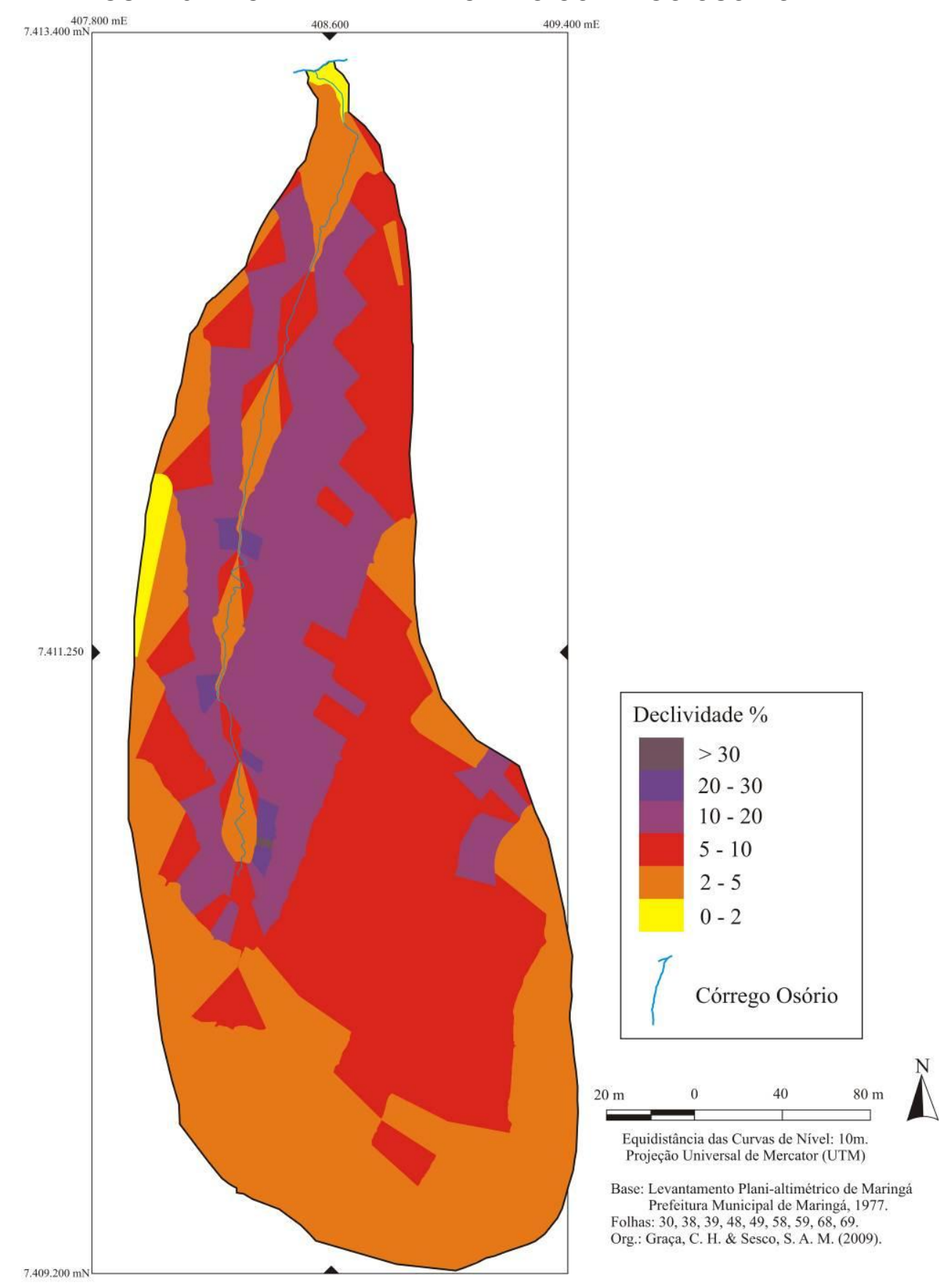

O conhecimento da declividade de um terreno se faz importante para que se possa realizar um planejamento mais adequado para o terreno, sem que haja possíveis transtornos como alagamentos e deslizamentos de terra. Do mesmo modo, o conhecimento da hipsometria é de fundamental importância em estudos relacionados ao uso e ocupação do espaço (Figura 4), pois o relevo exerce grande influência tanto no aspecto natural como no aspecto cultural de uma região, quando 
associado à geologia, clima e tipo de solo, possibilita verificar a forma mais adequada do uso e ocupação do solo (QUEIROZ, 2003).

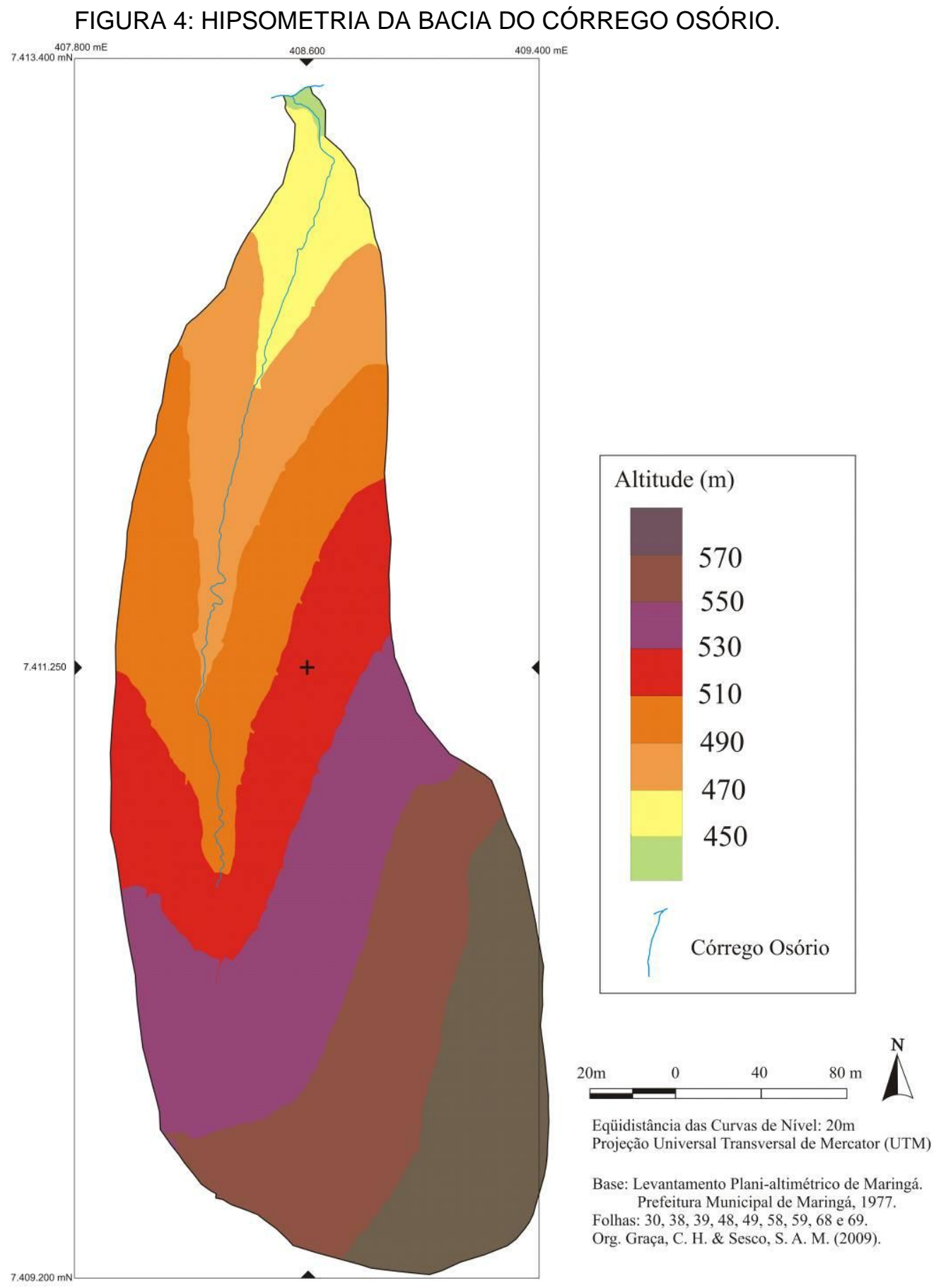

Em uma extensão aproximada de 2.817 metros do canal, a altitude da bacia do córrego Osório, varia de 450 a 570 metros acima do nível do mar (Figura 4). Apresentando uma variação altimétrica de aproximadamente 140 metros de desnível 
(Figura 5). A nascente do córrego encontra-se entre as cotas de 530 e 510 metros de altitude, e a sua foz na cota de 440 metros de altitude.

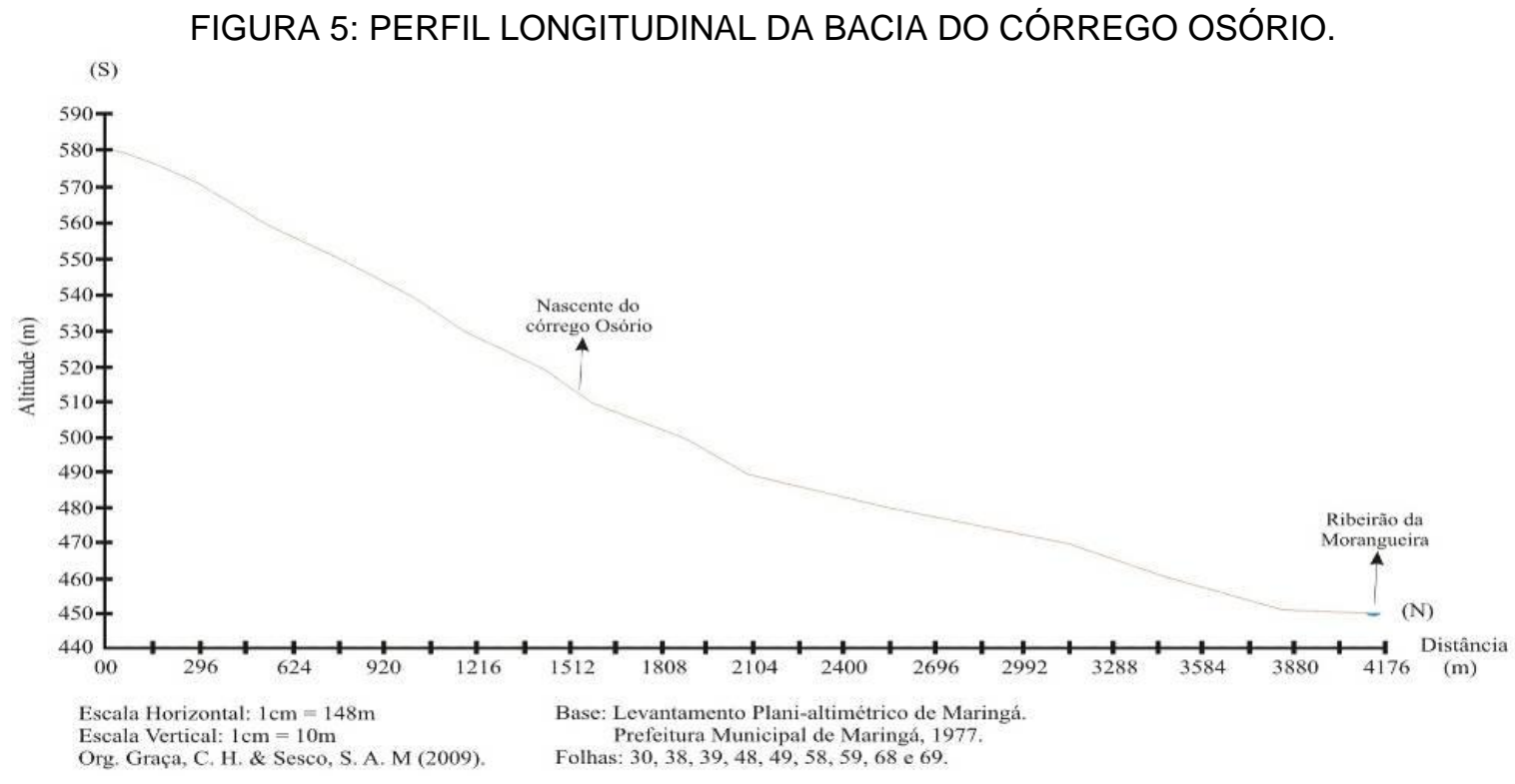

No entanto, Rigon (2005) quando refere-se a ocupação da bacia do Ribeirão da Morangueira, do qual o córrego Osório é afluente, discute as transformações da paisagem local, onde a mesma esteve exposta à forma de ocupação e uso do solo associada a uma dinâmica externa à região (cultura cafeeira). Embora não se possa descartar as passivas mudanças ocorridas no decorrer do tempo, influenciadas principalmente pela ação antrópica que em momentos distintos atua de maneira mais intensiva e agressiva.

Como conseqüência da expansão de núcleos urbanos na cidade de Maringá, a ocupação da bacia ocorreu principalmente à montante, no período de 1960 a 1980, evoluindo-se na década de 1990 e em 2003 em direção a jusante, a qual atualmente encontra-se praticamente toda ocupada (Figura 6). 
FIGURA 6: EVOLUÇÃO URBANA E LIMITE ENTRE OS BAIRROS DA BACIA DO CÓRREGO OSÓRIO.

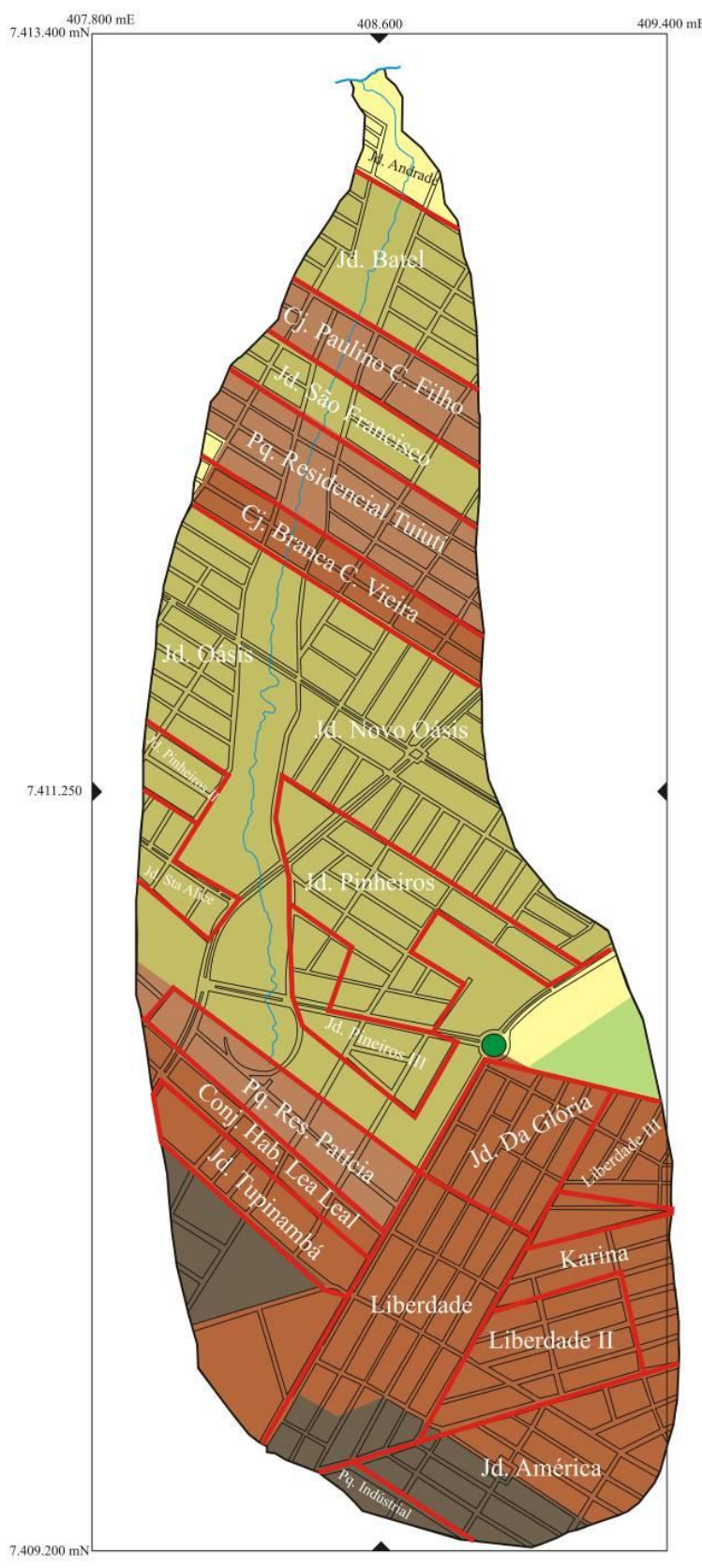

Evolução urbana da bacia do córrego Osório

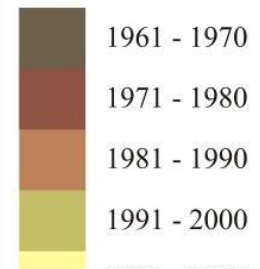

$2001-2008$

Cultura temporaria

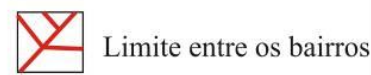

7 Ruas e Quarterões

Córrego Osório

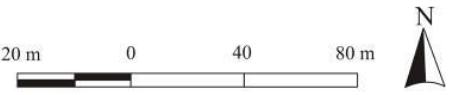

Projeção Universal de Mercator (UTM)

Base: Levantamento Plani-altimétrico de Maringá Prefeitura Municipal de Maringá, 1977 .
Folhas: $30,38,39,48,49,58,59,68,69$ Folhas: $30,38,39,48,49,58,59,68,69$ Org.: Graça, C. H. \& Sesco, S. A. M. (2009)

A população total existente nos bairros que estão dentro da área de abrangência da bacia do córrego Osório corresponde a 19.073 habitantes (IBGE, 2000). No entanto, cabe ressaltar que esse número de habitantes refere-se a valores totais nos bairros, pois quando se delimitou a bacia muitos destes bairros foram cortados ao meio, então não se inclui a área total dos 23 bairros localizados na delimitação da bacia (Figura 6). Dessa forma, considerando a quase totalidade da ocupação da bacia estudada, essa gerou a impermeabilização do solo, por meio de 
áreas construídas para moradia e comércio, além da pavimentação das ruas e calçadas.

$\mathrm{Na}$ atualidade, a impermeabilização do solo na bacia é muito aparente representando aproximadamente $78 \%$ da área total. Já os pontos não impermeabilizados encontram-se mais próximos ao curso d'água e nos terrenos baldios representa aproximadamente $22 \%$ da área total (Figura 7).

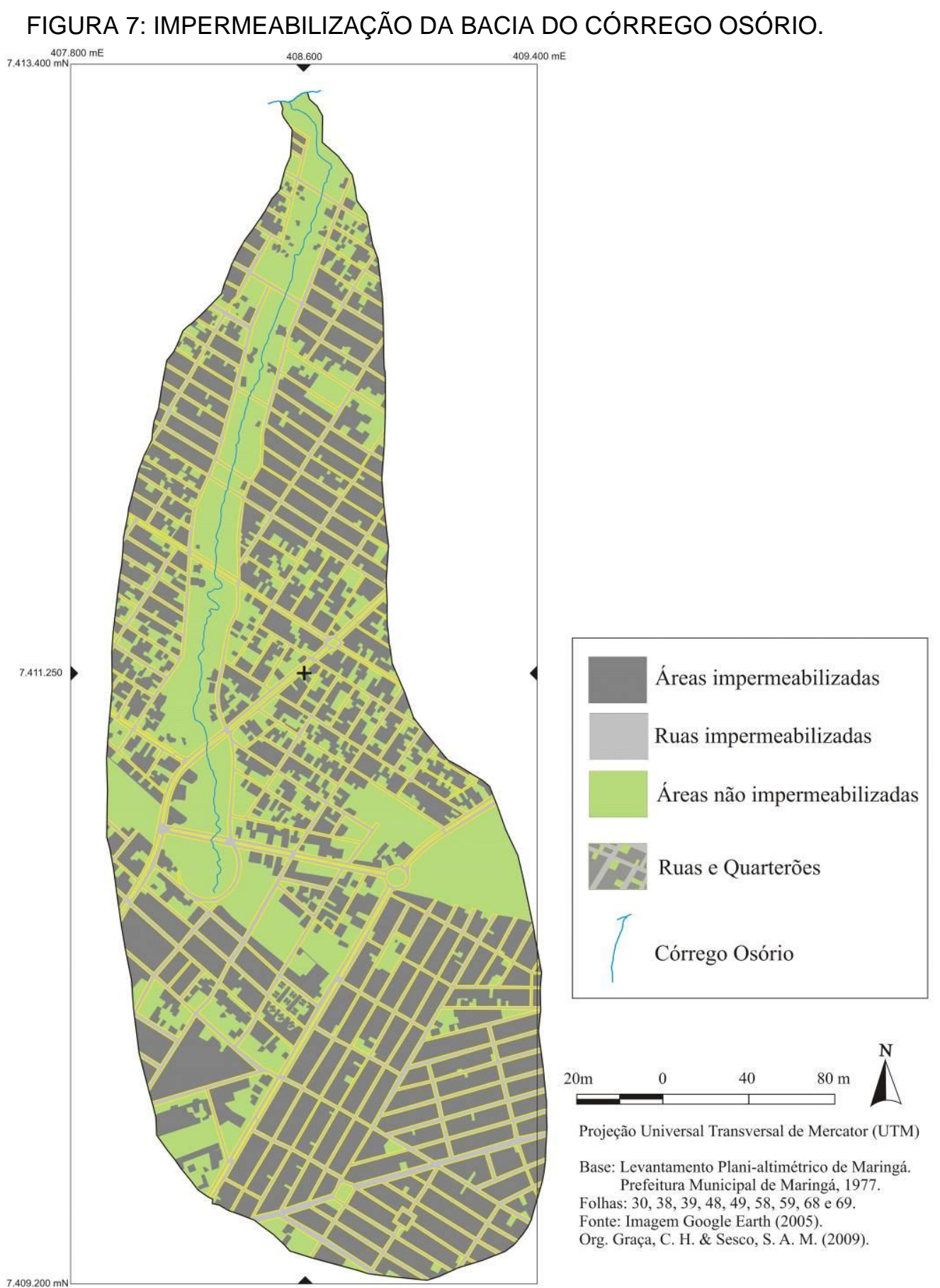


Essa realidade aparente de impermeabilização na bacia gera vários problemas, dentre alguns se faz importante ressaltar é a diminuição na percolação da água da chuva no solo, que tendem a escoar superficialmente até encontrar áreas não impermeabilizadas para infiltrar. Contudo, esse volume de água que chega a pontos sem a vegetação preservada ou solo nu que aparecem geralmente as margens do córrego, desenvolvem erosões laminares e transportes de sedimentos que são depositados no leito córrego.

Com essa vasta expansão urbana na bacia com a formação de vários bairros, as áreas agricultáveis foram dando lugar a ruas e avenidas, a residências e comércios, gerando conseqüências que se refletiram no ambiente local e sucessivamente na vida do córrego Osório. Deste modo, a vegetação foi a primeira a ser retirada para dar lugar à cafeicultura, que posteriormente deu lugar a infraestrutura dos bairros. A vegetação preservada apresenta um papel fundamental na absorção da água, diminuindo o impacto da mesma na superfície dos solos.

Na cidade de Maringá, de acordo com seu planejamento, a concentração da vegetação deveria estar nos parques ecológicos e nas áreas de preservação permanente, ou seja, no fundo de vales, desempenhando funções ecológicas e hidrológicas. Esta preservação está assegura no Código Florestal Brasileiro, Lei n. ${ }^{o}$ 4.771 de 15 de setembro de 1965, que determinou, no artigo $2^{\circ}$, que, ao longo dos rios ou de qualquer curso de água, a mata existente é considerada de preservação permanente, ou seja, deve ser preservada em sua forma nativa.

No córrego Osório, a vegetação arbórea que teria a função de proteger o solo de seu fundo de vale, ocorre de forma descontínua e reduzida (Figura 8), próximo ao curso d'água, mais precisamente na área delimitada para proteção permanente tendo o predomínio de vegetação mais rasteira como as gramíneas. Assim, como nas proximidades da nascente, que se apresenta em alguns pontos com vegetação arbórea e em outros pontos rasteira.

De modo geral, a falta de vegetação ciliar apresenta-se mais crítica nas proximidades da nascente, ocasionando maiores degradações nessa área, devido à diminuição da retenção de água no solo, do qual têm a função de abastecer os lençóis freáticos, gerando assim o escoamento superficial e sucessivamente os 
processos erosivos. Mas, pode-se observar ao longo de todo o curso do córrego, que são poucos os pontos que apresentam a vegetação ciliar de acordo com a legislação ambiental (Figura 8). Assim estas áreas que apresentam a vegetação permanente são aproximadamente $6 \%$ ou $229,9 \mathrm{~m}^{2}$ da área da bacia.

FIGURA 8: VEGETAÇÃO EXISTENTE E ÁREA DE PRESERVAÇÃO PERMANENTE NO CÓRREGO OSÓRIO.
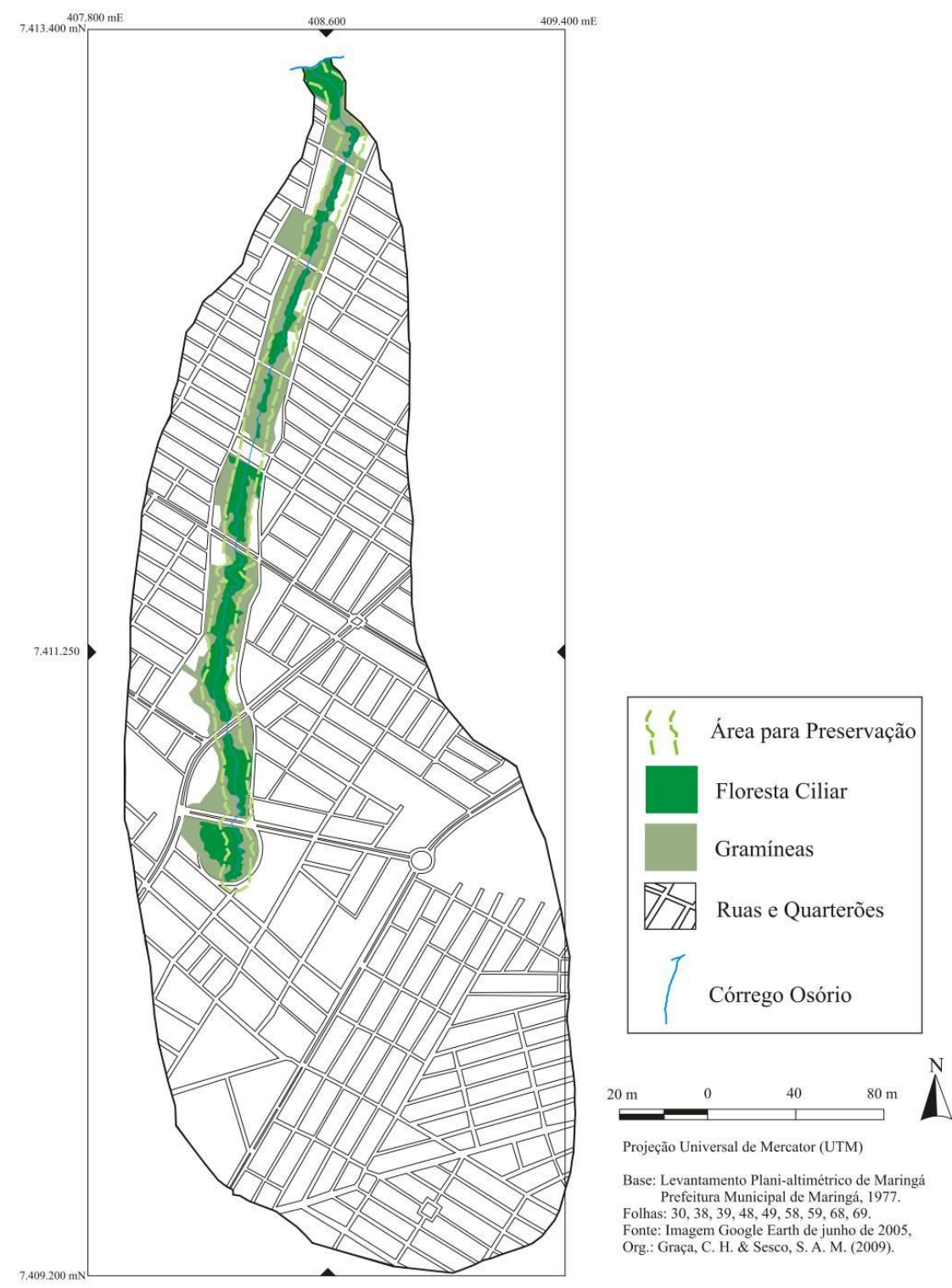

Projeção Universal de Mercator (UTM)

Base: Levantamento Plani-altimétrico de Maringá Prefeitura Municipal de Maringá, 1977 .
Folhas: $30,38,39,48,49,58,59,68,69$. Fonte: Imagem Google Earth de junho de 2005, Org.: Graça, C. H. \& Sesco, S. A. M. (2009).

Uma das principais conseqüências do desmatamento na cidade de Maringá são os processos erosivos nas margens dos rios. Apresentando como principais impactos ambientais causados pela erosão a perda do solo, de sua fertilidade natural, perda de umidade, formando erosão laminar e voçorocas. 
Nas margens do córrego Osório há uma grande presença de erosões laminares, intensificando-se a partir da emissão de águas pelos sistemas de galerias pluviais (Figura 9), onde as margens do córrego estão sendo escavadas, pelo impacto da água que chegam a esses locais, ocasionando também solapamentos em blocos nas margens e assoreamento de seu leito.

Embora não estando próximo ao curso do córrego, mas, dentro da área da bacia, os locais de empréstimo de terras, possibilitam a presença de processos erosivos no terreno, principalmente pela retirada da cobertura vegetal, facilitando assim o transporte desses sedimentos até seu leito.

FIGURA 9: PONTOS DE EROSÕES E EMPRÉSTIMO DE TERRA NA BACIA DO CÓRREGO OSÓRIO

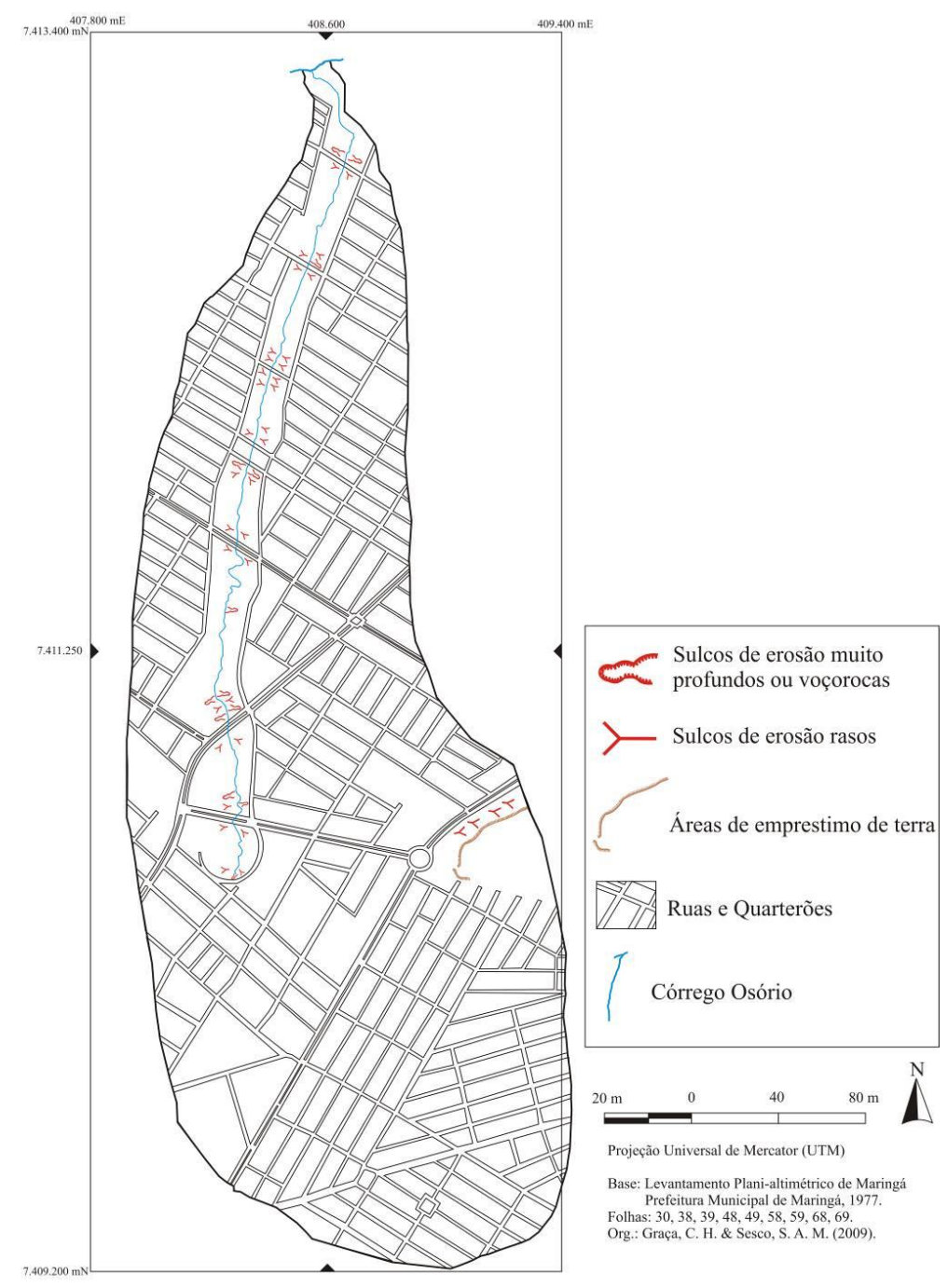


Um dos modos de diminuir a intensidade do escoamento superficial e sucessivamente as erosões de leito dos rios é a canalização das águas pluviais. 0 despejo desta água por galerias pluviais adequadas minimizam o impacto da água com o solo ou no leito do rio. Essas galerias pluviais são responsáveis por drenar a água da chuva não absorvida pelo solo, evitando inundações dentro do espaço urbano. No entanto, as construções das galerias pluviais, juntamente com a canalização do córrego em sete pontos, trouxeram problemas erosivos intensos ao córrego (Figura 10).

FIGURA 10: DISTRIBUIÇÃO DOS PONTOS DE DESPEJO DA ÁGUA DA CHUVA E CANALIZAÇÃO DO CURSO DO CÓRREGO OSÓRIO.

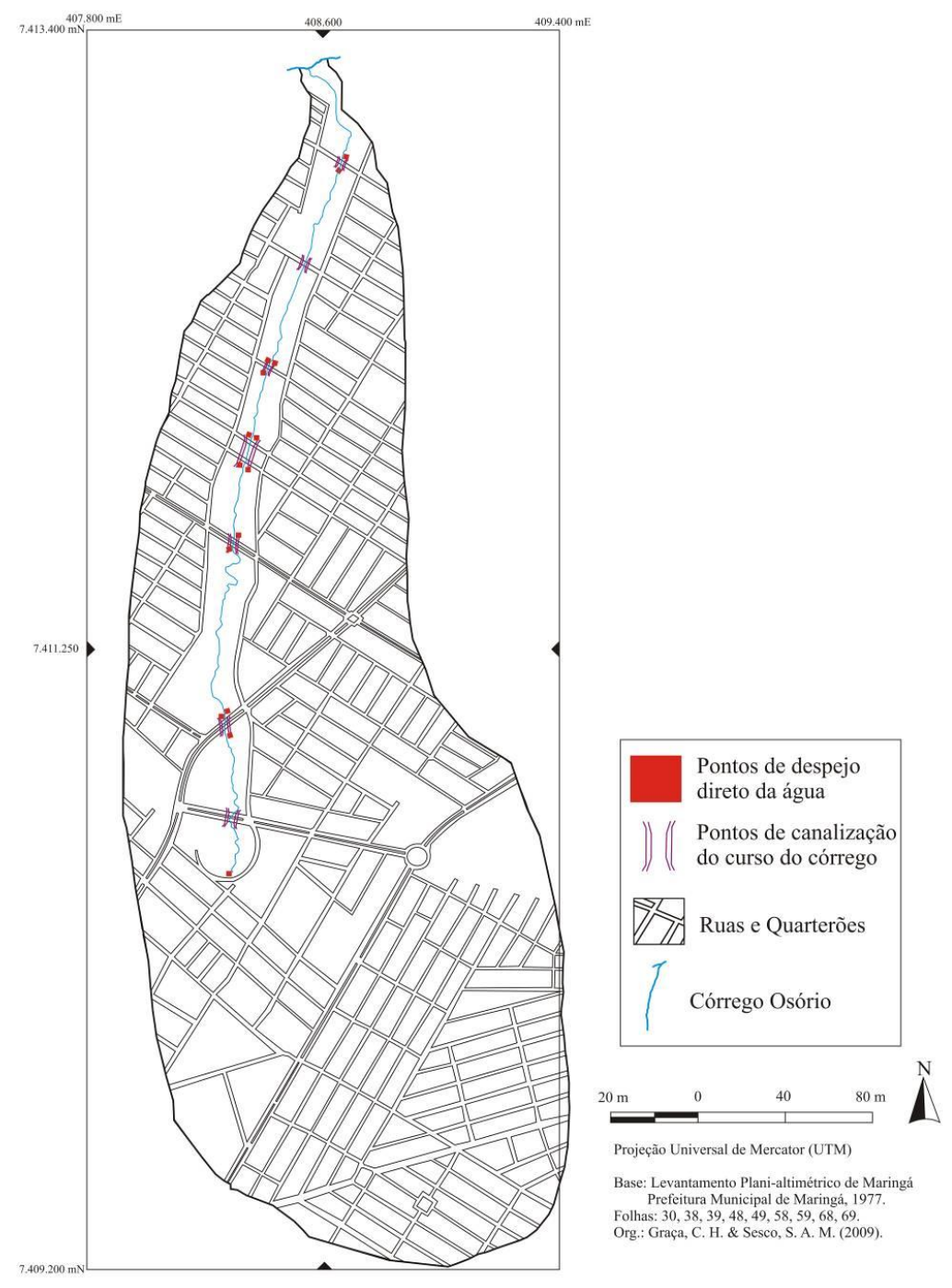

Em alguns locais no córrego, existe apenas a construção de um piso de concreto abaixo da saída de água dos tubos de canalização, provavelmente para 
diminuir o impacto da água no solo, entretanto, não diminui a velocidade e intensidade da água que chega ao seu leito. Ocorrendo assim, o despejo direto da água da chuva, favorecendo a escavação das margens do córrego.

A ocupação antrópica na bacia ocasionou outro problema, o despejo de resíduos sólidos em locais impróprios (Figura 11). Nas proximidades do córrego, em vários pontos foram encontrados lixo doméstico e os rejeitos provenientes da construção civil. Dentre os resíduos de origem doméstica foram identificados: sacolas plásticas, vidros, latas e caixa de papelão. Quanto os resíduos da construção civil encontrou-se madeiras, tijolos, azulejos e telhas.

FIGURA 11: CLASSES DE RESÍDUOS SÓLIDOS (LIXOS) E SUA DISTRIBUIÇÃO DENTRO DA BACIA DO CÓRREGO OSÓRIO.
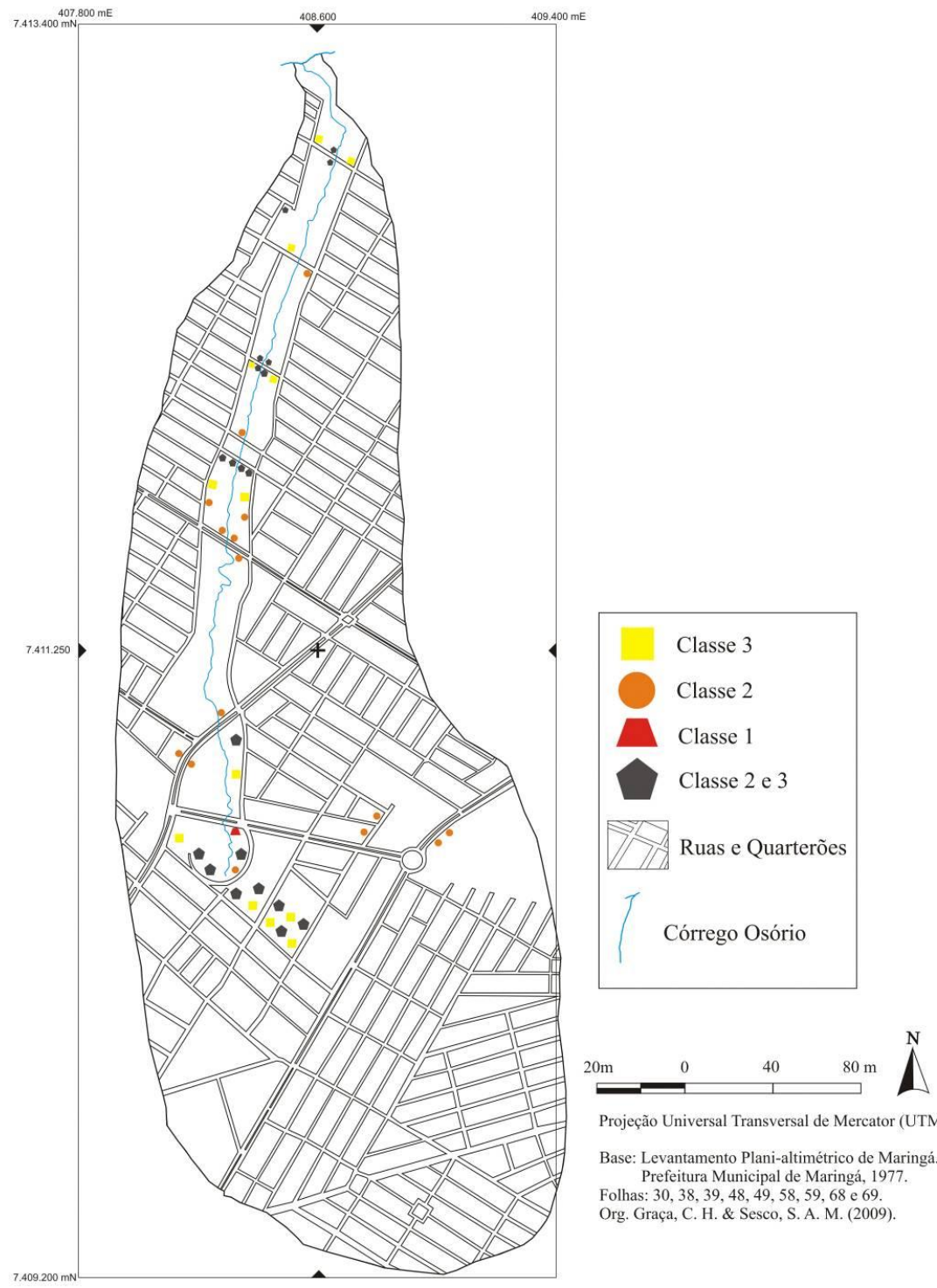

Projeção Universal Transversal de Mercator (UTM) Base: Levantamento Plani-altimétrico de Maringá. Prefeitura Municipal de Maringá, 1977 .
Folhas: $30,38,39,48,49,58,59,68$ e 69 Org. Graça, C. H. \& Sesco, S. A. M. (2009). 
Até mesmo, próximo a sua nascente o córrego Osório não escapa dos problemas como falta de vegetação, presença de processos erosivos ocasionados pelo escoamento superficial, despejo de resíduos sólidos, além do descarte de óleo misturado com areia.

Embora o ser humano, dependa da natureza para sua sobrevivência, pois precisa de água potável e do solo para a produção de alimento, também apresenta algumas necessidades que a tecnologia proporcionou, como por exemplo, o automóvel, ou outros meios de transportes. No entanto, para a sua utilização faz-se necessário a manutenção que ocorrerá nos postos de gasolina, nas oficinas mecânicas e nos lava-jatos, sendo que estes considerados como atividades comerciais impactantes. A poluição oriunda desses estabelecimentos pode trazer prejuízos ao meio ambiente, por meio da contaminação das águas superficiais, das águas subterrâneas e dos solos.

$\mathrm{Na}$ bacia do córrego Osório existe diversos estabelecimentos dessa natureza (Figura 12), onde foram identificados 53 (Quadro 2).

QUADRO 2: LOCALIZAÇÃO, TIPO DE ESTABELECIMENTO COMERCIAL IMPACTANTE E QUANTIDADE NA BACIA DO CÓRREGO OSÓRIO.

\begin{tabular}{|l|l|c|}
\hline \multicolumn{1}{|c|}{ Localização } & \multicolumn{1}{|c|}{ Estabelecimento } & Quantidade \\
\hline Avenida das Indústrias & Oficinas Mecânicas & 01 \\
\hline Avenida Osíris Guimarães & Oficinas Mecânicas & 06 \\
\hline \multirow{2}{*}{ Avenida dos Palmares } & Lava-jatos & 02 \\
\cline { 2 - 3 } & Oficinas Mecânicas & 04 \\
\hline Avenida Guaiapó & Oficina Mecânica & 09 \\
\hline \multirow{3}{*}{ Avenida Tuiutí } & Lava-jatos & 01 \\
\cline { 2 - 3 } & Postos de Gasolina & 04 \\
\cline { 2 - 3 } & Oficinas Mecânicas & 06 \\
\hline Avenida Dr. Alexandre Rasgulaeff & Oficina Mecânica & 01 \\
\hline Avenida Jinroko Kubota (Av. das Torres) & Posto de Gasolina & 01 \\
\hline \multirow{3}{*}{ Avenida Dona Sophias Rasgulaeff } & Lava-jatos & 01 \\
\cline { 2 - 3 } & Postos de Gasolina & 01 \\
\cline { 2 - 3 } & Oficinas Mecânicas & 12 \\
\hline Rua Rio Guandu & Oficina Mecânica & 01 \\
\hline Rua 28 de Junho & Oficina Mecânica & 01 \\
\hline Rua Frei Caneca & Oficina Mecânica & 01 \\
\hline Rua Hebert Mayer & Oficina Mecânica & 01 \\
\hline
\end{tabular}

Org.: SESCO, Sandra (2009). 
No entanto, cabe direcionar a atenção aos estabelecimentos localizados próximos ao córrego Osório, aonde se encontra dois postos de gasolina. Além de oferecer serviço de abastecimento de combustível, esses postos ainda fornecem serviço de lavagem e troca de óleo.

FIGURA 12: LOCALIZAÇÃO DOS LAVA JATOS, POSTOS DE GASOLINA E OFICINAS MECẨNICAS NA BACIA DO CÓRREGO OSÓRIO.

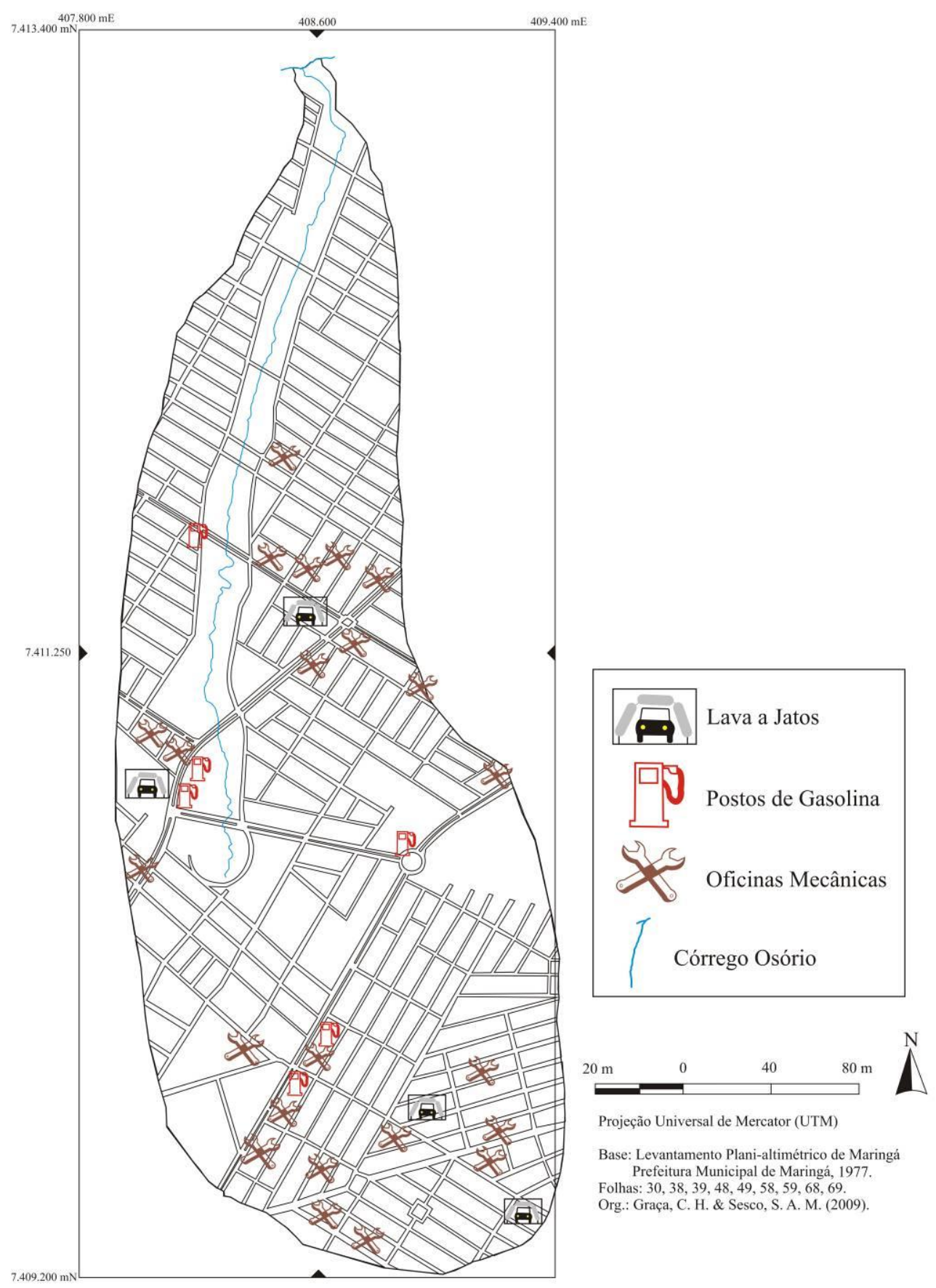


Os postos de combustíveis produzem as três classes de resíduos sólidos destacados pela NBR 10.004/2004, entretanto, os de maior periculosidade compreendem o lodo das caixas separadoras, resíduos de óleo, graxa, materiais contaminados com óleos e panos, estopas com graxa, dentre outros. Esses tipos de resíduos apresentam riscos à saúde e ao meio ambiente, exigindo dessa forma, tratamento e disposição especial devido suas características de inflamabilidade, corrosividade, reatividade e patogenecidade (BORSATO, 2005).

\section{CORRELAÇÃO DOS DADOS}

Para que os problemas relacionados sejam minimizados no espaço urbano, Cavalheiro (1995) sugere que sejam feitas análises e diagnóstico da paisagem, de modo que se tenha claro qual deve ser a proporção ideal de análise e diagnóstico de espaços construídos e livres de construção que o ecossistema suportará, criando um ambiente urbano mais integrado com a natureza.

Por meio da carta de correlação, pode-se observar a integração dos problemas encontrados na bacia do córrego Osório, relacionado principalmente com a ação antrópica, a partir de sua ocupação e urbanização.

Assim, à medida que se intensifica a ocupação, os problemas aumentam proporcionalmente nas margens do córrego. Contudo, a correlação das informações possibilitou a visualização dos pontos onde estão os pontos com maior degradação e impacto ambiental dentro da bacia (Figura 13). 
FIGURA 13: CORRELAÇÃO DAS INFORMAÇÕES OBTIDAS NA BACIA DO CÓRREGO OSÓRIO.

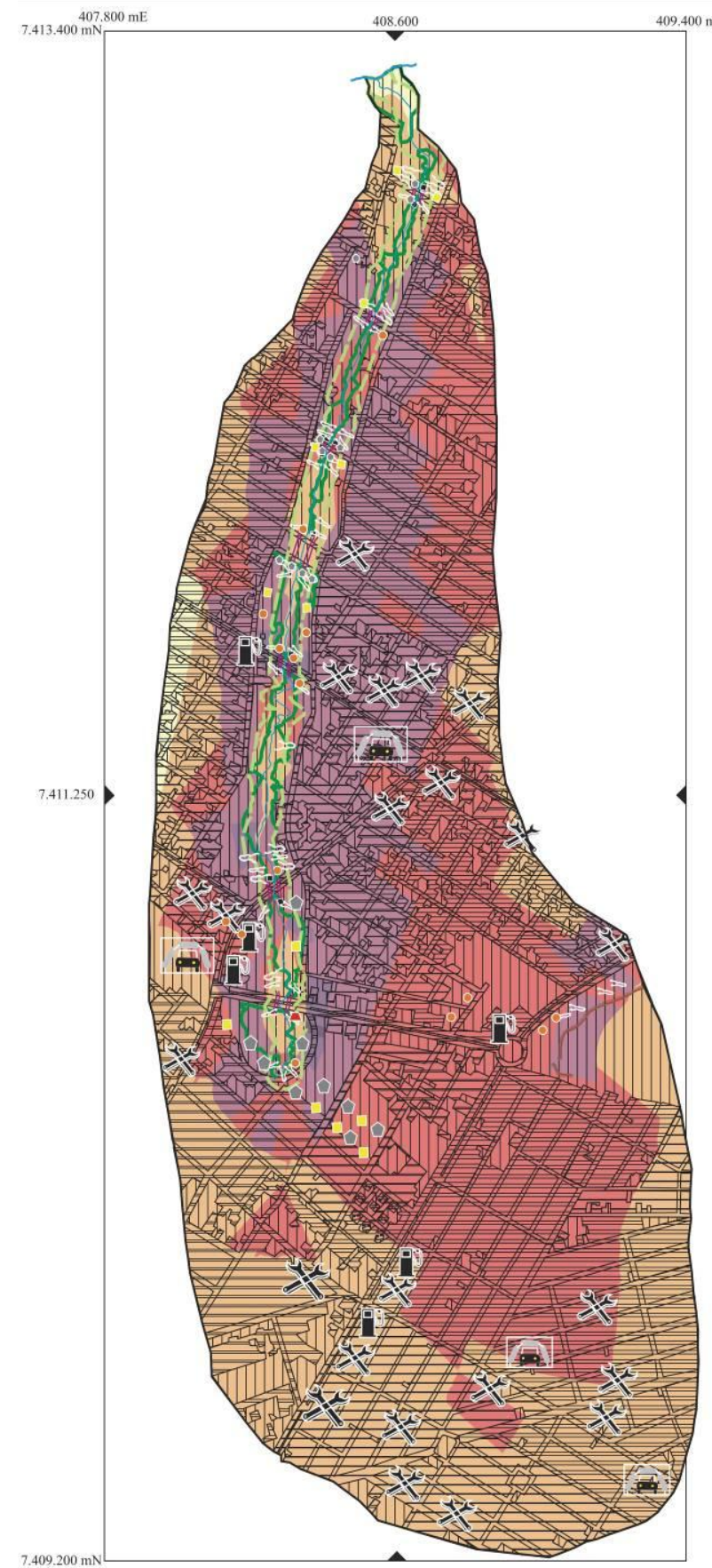

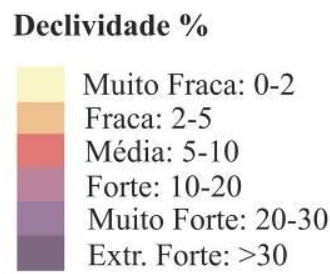

II Sem Impermeabilização Impermeabilizado

Despejo Galerias Pluviais

Despejo Direto

I) ([ Pontos de Canalização Erosões

Empréstimo de Terra Sulcos Profundos ou Voçorocas Sulcos rasos

Vegetação

య Floresta Ciliar Área para Reflorestamento

Classes de Resíduos

- Classe 1

- Classe 2

- Classe 3

- Classe 2 e 3

Estabelecimentos Comerciais

D Postos de Gasolina

Xf Oficinas Mecânicas

a Lava a Jatos

T

Córrego Osório

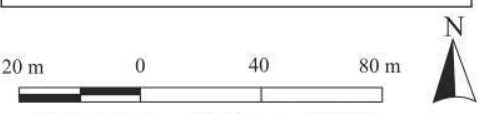

Projeção Universal de Mercator (UTM)

Base: Levantamento Plani-altimétrico de Maringá Prefeitura Municipal de Maringá, 1977. Folhas: $30,38,39,48,49,58,59,68,69$.

\section{CLASSES DE FRAGILIDADE E/OU VULNERABILIDADE SÓCIO-AMBIENTAL}

Quando em determinado espaço ocorrem várias ações, as mesmas podem ser mapeadas e as informações obtidas correlacionadas, chegando a um mapa síntese, que representará os locais com maior e/ou menor susceptibilidade a degradação seja ela natural ou antrópica. 
Dessa forma, a maior porção da bacia foi classificada com fragilidade e/ou vulnerabilidade sócio-ambiental Forte com aproximadamente $53 \%$ ou $2.03 \mathrm{~km}^{2} \mathrm{da}$ área da bacia (Figura 14). Para atingir esta classe considerou-se a soma dos atributos correlacionados, resultando na somatória que estivesse dentro do intervalo de 11 a 18 pontos. As declividades predominantes variam entre forte a extremamente forte, dentre os problemas levantados merecem destaque a impermeabilização e a falta da vegetação, em menor proporção o despejo de resíduos sólidos e presença de atividades comerciais impactantes.

Contendo acima de 18 pontos em seus atributos correlacionados, a classe de fragilidade e/ou vulnerabilidade sócio-ambiental Muito Forte corresponde a aproximadamente $11 \%$ ou $0,421 \mathrm{~km}^{2}$ da área da bacia (Figura 14). Esta classe ocorre onde os atributos correlacionados são os mais desfavoráveis.

A classe de fragilidade e/ou vulnerabilidade sócio-ambiental Média que corresponde a aproximadamente $24 \%$ ou $0,919 \mathrm{~km}^{2}$ da área da bacia (Figura 14), encontram-se entre os intervalos de 8 a 10 pontos. A declividade do terreno varia de média a muito fraca, nesses locais a maior parte da superfície encontra-se impermeabilizada, há falta de vegetação natural e elevada quantidade de estabelecimentos comerciais de atividades impactantes.

A classe de fragilidade e/ou vulnerabilidade sócio-ambiental Baixa que corresponde a aproximadamente $12 \%$ ou $0,460 \mathrm{~km}^{2}$ da área da bacia (Figura 14), foi estabelecida com a soma dos atributos de 2 a 7 pontos. Localizadas de forma dispersa dentro da bacia, estão presentes em todas as declividades, em locais que apresenta vegetação e áreas não impermeabilizadas, como terrenos baldios que não apresentam a deposição de resíduos sólidos, ou outro atributo estudado considerado problemático. 
FIGURA 14: CLASSES DE FRAGILIDADE E/OU VULNERABILIDADE SÓCIO-AMBIENTAL DA BACIA DO CÓRREGO OSÓRIO.

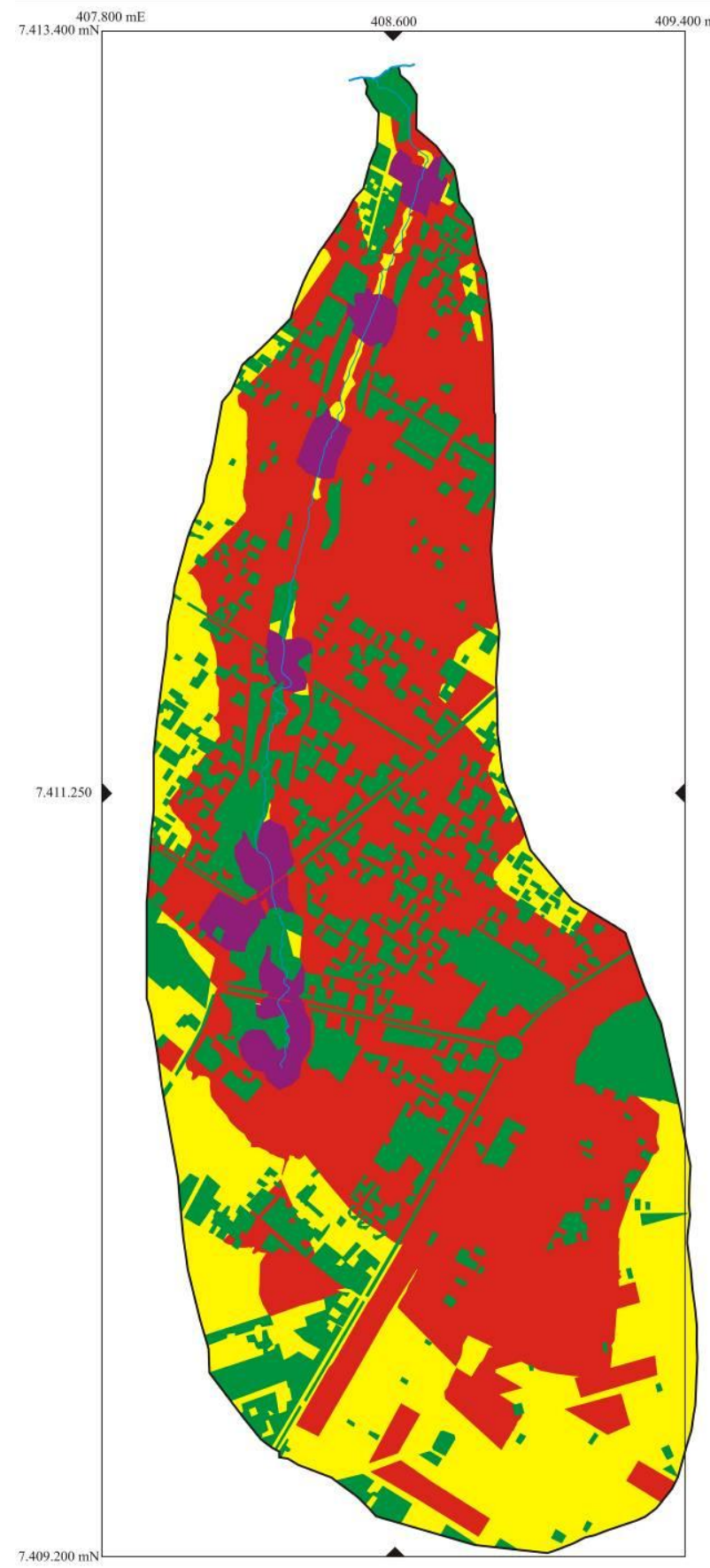

Classes de fragilidade e/ou vulnerabilidade sócio-ambiental da bacia do córrego Osório

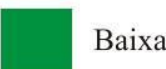

Média

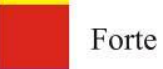

Forte

Muito Forte
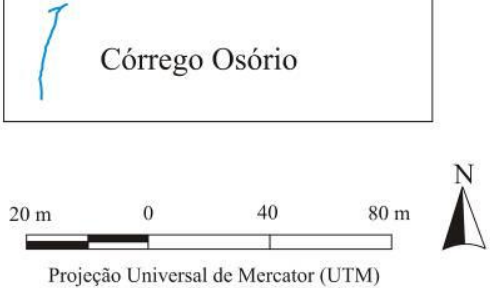

Base: Levantamento Plani-altimétrico de Maringá

Prefeitura Municipal de Maringá, 1977 .

Folhas: $30,38,39,48,49,58,59,68,69$.

Org.: Graça, C. H. \& Sesco, S. A. M. (2009).

\section{CONSIDERAÇÕES FINAIS}

Inserida no espaço urbano da cidade de Maringá, a bacia do córrego Osório, apresenta problemas ambientais intensos, principalmente ocasionados pela ação antrópica. 
A maior concentração de problemas na bacia está nas proximidades do curso d'água, não estando presentes os estabelecimentos comerciais de atividades impactantes, mas, apresentando processos erosivos, falta de vegetação, ocorrência de despejos de resíduos sólidos, emissão de águas sem sistemas de contenção e impermeabilização do solo em áreas próximas, principalmente onde ocorre a canalização do córrego. Assim, um trabalho de conscientização faz-se necessário.

As obras de engenharia e impermeabilização do solo possivelmente não podem sem modificadas, no entanto, é possível a conscientização da utilização da água da chuva e implantação de calçadas ecológicas dentro da área da bacia estuda possibilitando a infiltração da água no solo.

Os processos erosivos ocasionado pelo escoamento superficial em áreas sem impermeabilização é um fator natural, embora intensificada pela impermeabilização do solo, nos locais onde existe o despejo direto das águas pluviais, a construção de sistemas de contenção teria a finalidade de diminuir a velocidade das águas lançadas em rios.

Os problemas relacionados aos resíduos sólidos podem ser trabalhados com a população, no sentido de conscientizar para dar o direcionamento ideal aos diferentes tipos de lixos, assim como é necessário à fiscalização dos órgãos responsáveis pelo licenciamento e liberação da implantação de oficinas, postos de gasolinas e lava-jatos para verificar há ocorrência de despejo de materiais poluentes no ambiente.

Se o ambiente não está em equilíbrio é necessário que haja estudos contínuos, para que a degradação e o impacto ao longo dos anos não se tornem irreversíveis, sem mais nenhuma possibilidade de recuperação destas áreas.

\section{REFERÊNCIAS}

ANJOS, I. B. Caracterização climática para a região de Maringá. Monografia de conclusão de curso: Departamento de Geografia - Universidade Estadual de Maringá. Maringá. 2000.

ASSOCIAÇÃO Brasileira de Normas Técnicas (ABNT). Resíduos sólidos. NBR 10004. Rio de Janeiro: ABNT, 1989. 
BORSATO, F. H. Caracterização física das bacias de drenagem do Município de Maringá e os postos de combustíveis como potenciais poluidores. Dissertação (Mestrado). Universidade Estadual de Maringá. Programa de Pós-graduação em Geografia. Maringá, 2005.

BRASIL. Lei № 4.771, de 15 de Setembro de 1965. Disponível em $<$ http://www.planalto.gov.br/ccivil_03/Leis/L4771.htm>. Acesso em 11 de março de 2009.

CAVALHEIRO, F. Uso dos solos altamente suscetíveis à Erosão. In: PEREIRA, V. P.; FERREIRA, M. E.; CRUZ, M.C.P. Solos altamente suscetíveis à Erosão. FCAVUNESP/SBCS: Jaboticabal, 1995.

CREPANI, E; MEDEIROS, J.S.; AZEVEDO, L.G.; DUARTE, V.; HERNANDES, P.; FLORENZANO, T. Curso de Sensoriamento Remoto Aplicado ao Zoneamento Ecológico-Econômico. INPE: São José dos Campos - SP, 1996.

EMPRESA Brasileira de Pesquisa Agropecuária (EMBRAPA). Manual de métodos de análise do solo. Centro Nacional de Pesquisa de solo: Rio de Janeiro, 1999.

GARCIA, J. C. Maringá Verde? O desafio ambiental na gestão das cidades. Eduem: Maringá, 2006.

GRAÇA, C. H. Avaliação da degradação e do impacto sócio-ambiental na bacia do córrego Esperança, Maringá - PR. Monografia de conclusão de curso, Departamento de Geografia: Universidade Estadual de Maringá. Maringá, 2008.

GRAÇA, C. H.; SILVEIRA, H. Avaliação da degradação e do impacto sócioambiental na bacia do córrego Esperança, Maringá - PR. In: XIII Simpósio Brasileiro de Geografia Física Aplicada - UFV. Viçosa, 2009.

GUIA Comercial da Cidade de Maringá. 9º edição. Contado: Maringá, 2008.

INSTITUTO Agronômico do Parná (IAPAR). Cartas climáticas básicas do Estado do Paraná. IAPAR: Londrina, 1978.

INSTITUTO Brasileiro de Geografia e Estatística (IBGE): Censo 2000. Disponível em <http://www.sidra.ibge.gov>. Acesso em 20 de maio de 2009.

LUZ, F. O fenômeno urbano numa zona pioneira: Maringá. Prefeitura Municipal de Maringá, São Paulo, 1997.

MAACK, R. Geografia Física do Estado do Paraná. Clichês. Curitiba, 1968.

MENDES, C. M.; GRZEGORCZYK, V. Centro, centralidade e verticalização de Maringá. In: MORO, Dalton A. (org.) Maringá Espaço e Tempo. Programa de PósGraduação em Geografia, UEM. Maringá, 2003.

MINEROPAR. Mapa Geológico do Estado do Paraná, 2006. Disponível em $<w w w . m i n e r o p a r . p r . g o v . b r / F i l e / M a p a s P D F / g e o l o g o c o s / g e o l o g i c o \_650 . p d f>$. Acesso março de 2009. 
MORO, D. A. (org.) Maringá Espaço e Tempo. Programa de Pós-Graduação em Geografia, UEM: Maringá, 2003.

PARANÁ (Secretária do Estado da Agricultura e do Abastecimento, Instituto de Terras, Cartografia e Florestas). Atlas do Estado do Paraná. Curitiba, 1987.

PREFEITURA Municipal de Maringá. Levantamento Plani-altimétrico do município de Maringá. 1977. Disponível em

<ftp://ftp.uem.br/UEM/Cartografia_Digital/Planialtimetrica/>. Acesso em fev. de 2009.

PREFEITURA Municipal de Maringá. Superintendência de Desenvolvimento Urbano e Habitacional. (SEDUH). Maringá, 2000.

QUEIROZ, D. R. E. Atlas geoambiental de Maringá - da análise a síntese: a cartográfica como subsídio ao planejamento de uso e ocupação do espaço. Clichetec: Maringá, 2003.

RIGON, O. Desenvolvimento Local e meio ambiente: produção do espaço e problemas ambientais - a Bacia hidrográfica do Ribeirão da Morangueira/Maringá$P R$. Dissertação de Mestrado. Programa Pós-Graduação em Geografia. Universidade Estadual de Maringá. Maringá, 2005.

SIMIELLI, M. E. R. Cartografia no ensino fundamental e médio. A Geografia na Sala de Aula. Contexto: São Paulo, 1999.

STRAHLER, A. N. Quantitative geomorphology of drenaige basins and channel networks. In.: Chow, vent e - Handbook of Applied Hidrology. New York, MecGrawHill Book, 1964

TUCCI, C. E. M. Inundações urbanas. In: TUCCI, C. E. M.; PORTO, R. L.; BARROS, M. T. Drenagem Urbana. ABRH/Editora da Universidade/UFRGS: Porto Alegre, 1995.

ZAMUNER, L. D. Erosão urbana em Maringá/PR: o caso do Parque Florestal dos Pioneiros - Bosque II. Dissertação (mestrado) - Programa de Pós-Graduação. Universidade Estadual de Maringá. Maringá, 2001.

(Recebido em fevereiro/2010. Aceito em maio/2010) 